\title{
Organosilane-Functionalized Graphene Oxide Hybrid Material: Efficient Adsorbent For Heavy Metal lons In Drinking Water
}

\section{Muharrem KARABÖRK}

Sütçü İmam University

\section{Ban Abdullelah Muhammed}

Sütçü İmam University

\section{Mehmet TÜMER}

Sütçü İmam University

SERHAN URUŞ ( $\nabla$ serhanurus@yahoo.co.uk)

Kahramanmaraş Sutcu Imam Universitesi Tip Fakultesi https://orcid.org/0000-0002-4204-9860

\section{Research Article}

Keywords: Graphene oxide, solid phase extraction, heavy metals, material

Posted Date: May 11th, 2021

DOl: https://doi.org/10.21203/rs.3.rs-499116/v1

License: (c) (i) This work is licensed under a Creative Commons Attribution 4.0 International License. Read Full License

Version of Record: A version of this preprint was published at Phosphorus, Sulfur, and Silicon and the Related Elements on December 10th, 2021. See the published version at https://doi.org/10.1080/10426507.2021.2012676. 


\section{Abstract}

Organosilane-functionalized and chemically activated graphene-supported Schiff base ligand were synthesized and characterized with XRD, SEM, EDX, TEM, UV.-Vis., FT-IR and TG/DTA techniques. In the synthesis process, graphene oxide was firstly obtained with Hummer' s method and reacted with 3(trimethoxysilyl)propylamine. The last, the amine-activated and organosilane containing GO was reacted with 3,5-di-tert-butylsalicylaldehyde resulting the hybrid material (M) having azomethine group. The material (M) was used as an adsorbent in order to remove the cobalt(II) and zinc(II) ions in drinking water and standard solutions. The adsorption capacity of the material (M) to cobalt(II) and zinc(II) ions was investigated by batch method. Moreover, the effect of $\mathrm{pH}$, contact time, temperature, and concentration on the adsorption capacity of the material was also investigated. The enrichment factors were calculated as 441 and 675 for zinc(II) and cobalt(II), respectively. The recovery performance of the material was determined in $98.65-101.75 \%$ and $98.55-104.0 \%$ range for zinc(II) and cobalt(II) ions, respectively.

\section{Highlights}

- The imine-graphene hybrid material (HL) was synthesized.

- The hybrid material (HL) was used as an adsorbent for removal of the Co(II) and $\mathrm{Zn}(\mathrm{II})$ metal ions.

- The chemical structures of the hybrid material( $\mathrm{HL})$ were characterized by the FT-IR, XRD, EDX, SEM, TEM and Uv-vis techniques.

- Adsorption capacity of the hybrid material toward Co(II) and Zn(II) metal ions were investigated.

- The effects of $\mathrm{pH}$, contact time, temperature, and concentration on the adsorption properties of the hybrid material were investigated.

\section{Introduction}

Waste waters containing heavy metal ions are considered as the serious environmental problem in human society. Zinc is one of the essential elements found in biological systems and found in the active site of many enzymes [1,2]. However, the presence of excess amount of zinc in biological systems can be harmful to the environment as well as living beings that is considered as toxic above the certain limits [3]. There are several symptoms for zinc toxicity including irritability, nausea, loss of appetite and muscular stiffness [4]. The metals can also bioaccumulate in the flora and fauna resulting in ecological problems. The World Health Organisation (WHO) reported the recommended level of zinc in drinking water as 5 $\mathrm{mg} / \mathrm{L}$ [5]. Some work conditions such as asmining, purifying zinc, lead and cadmium ores, steel production and coal burning and burning of wastes increases the concentration of the metal ion to the above of the certain limits. Several methods have been developed for the removal of zinc from waste and drinking waters [6-10]. Cobalt is another essential element found in biological systems and found in varius forms in the earth's crust [11]. This metal can also be toxic above the certain concentration and cause healt problems including low blood pressure, lung irritation, paralysis, diarrhea, bone defects, and genetic changes in living cells $[12,13]$. The methods for the removal of cobalt from waste and drinking 
waters include precipitation, reverse osmosis, co-precipitation, ion-exchange, membrane, electrolysis, oxidation and adsorption methods [14-18].

Solid phase extraction technique with adsorption has been widely getting studied in wastewater treatment that is based on the physical interaction between metal ions and sorbents. While developing the synthesis of new nanomaterials such as, graphene oxide and graphene oxide based hybrid materials are used also as sorbents in waste water treatment [19]. It is considered to be one of the most effective and economical treatment methods for heavy metal ions removal of effluents, rivers etc. Because of the fact that it can be easily designed and functionalized chemically and the obtained structures have unique physicochemical properties and surface, it is attracted as multidisciplinary area by the scientists. The functional groups on the graphene oxide surfaces have high surface area and show some potential for the removal of heavy metal ions from aqueous solutions [20].

In this work, firstly, graphite was oxidized according to Hummer's method forming graphene oxide (GO). After, GO-APTMS was synthesized with the reaction of GO and 3-(trimethoxysilyl) propylamine (APTMS). The obtained GO-APTMS having free primary amine substituents $\left(-\mathrm{NH}_{2}\right)$ was reacted with the 3,5,di-tertbutyl-2-hydroxy-benzenaldehyde to form the material $(M)$. The novel Schiff base ligand supported on organosilane containing GO as a hybrid material was characterized by the EDX, SEM, TEM, XRD, TGA, UV and FT-IR methods. The synthesized and characterized hybrid material was used as adsorbent for the removal of cobalt(II) and zinc(II) ions from drinking water using batch method. Selectivity and reusability of the graphene based material towards cobalt(II) and zinc(II) metal ions have been investigated.

\section{Experimental}

\subsection{General}

Graphite powder was supplied from Sigma-Aldrich(St. Louis, USA). $\mathrm{H}_{2} \mathrm{SO}_{4}$ and $\mathrm{KMnO}_{4}$ were purchased from Sigma-Aldrich (Germany). $\mathrm{H}_{2} \mathrm{O}_{2}, \mathrm{HCl}$ and $\mathrm{NaOH}$ were purchased from Merck. 3-(Trimethoxysilyl) propylamine was obtained from Sigma-Aldrich. Absolute ethanol and methanol were obtained from Sigma-Aldrich. 3,5-di-tert-butyl salicylaldehyde was supplied from Aldrich. Standard solutions of $\mathrm{Co}(\mathrm{II})$ were prepared from $\mathrm{CoCl}_{2} \cdot 6 \mathrm{H}_{2} \mathrm{O}$ and $\mathrm{Zn}$ (II) solutions were prepared from $\mathrm{ZnCl}_{2} \cdot 2 \mathrm{H}_{2} \mathrm{O}$. Merck 119806 CertiPUR ${ }^{\circledR}$ for Zn(II) and Sigma Aldrich 49564 TraceCERT ${ }^{\circledR}$ for Co(II) were used certified solutions.

\subsection{Instrumental}

Infrared spectra were obtained using $\mathrm{KBr}$ disc $\left(4000-400 \mathrm{~cm}^{-1}\right)$ on a Perkin Elmer Spectrum $100 \mathrm{FT}$-IR. The electronic spectra in the $200-900 \mathrm{~nm}$ range were obtained on a Perkin Elmer Lambda 45 spectrophotometer. The thermal studies of the compounds were performed on a Perkin Elmer STA 6000 simultaneous Thermal Analyzer under nitrogen atmosphere at a heating rate of $10^{\circ} \mathrm{C} / \mathrm{min}$. The quantity of the $\mathrm{Co}(\mathrm{II})$ and $\mathrm{Zn}$ (II) ions obtained from the aqueous solutions was determined by Inductive Coupled 
Plasma- Optical Emission Spectrometer (ICP-OES) (Perkin Elmer Brand Optima 2100 DV). All experimental conditions were kept the same for all samples. X-ray diffraction (XRD) patterns of the GO, APTES-GO and hybrid material were conducted by using a Philips X'Pert Pro X-ray diffractometer (XRD), with $\mathrm{Cu}-\mathrm{Ka}$ radiation. Scanning range was $0-60^{\circ}$ and taken as $2 \theta$. The surface morphologies of the samples were measured by a scanning electron microscope (SEM, EVOLS10 Zeiss) and a transmission electron microscope (TEM, JEOL JEM2010), respectively. The surface morphology and EDX analysis of the nanocomposite ligands and the complexes were analyzed using Zeiss Evo LS10 SEM attached with Bruker Quantax EDS. Hanna HI 2211-05 desktop pH meter was used for pH adjustments of the solutions. Graphene oxide sheets, silanization derivative and hybrid structures were analyzed using a High Resolution images in Transmission Electron Microscopy mode (HRTEM) Joel JEM 2100 F TEM, which has a point resolution of $0.18 \mathrm{~nm}$ at $200 \mathrm{Kv}$ and room temperature. The TEM analyses included amplitude-contrast bright field (BF) images and HRTEM images.

\subsection{Preparation of graphene oxide (GO)}

GO has been synthesized by the route of Hummer's method [21]. Shortly, the powder graphite (5 g), $\mathrm{NaNO}_{3}(2.5 \mathrm{~g})$ and concentrated $\mathrm{H}_{2} \mathrm{SO}_{4}(98 \%)(115 \mathrm{~mL})$ were mixed and the mixture was mixed during $1 \mathrm{~h}$ on the ice bath. After the mixing, $\mathrm{KMnO}_{4}(15 \mathrm{~g})$ was added to the suspension and the mixture was heated to $90{ }^{\circ} \mathrm{C}$ until the color changed from brown to bright yellow. The GO was filtered, washed with plenty of water and dried at room temperature.

\subsection{Preparation of GO-APTMS}

The obtained GO (1g) and 3-(trimethoxysilyl)propylamine $(1 \mathrm{~g})$ in ethanol $(50 \mathrm{~mL})$ were mixed and the reaction solution was refluxed for 48 hours. The reaction mixture was then cooled to room temperature and the obtained product GO-APTMS was dried at room temperature.

\subsection{Preparation of the material (M)}

The GO-APTMS (1g) and the carbonyl compound 3,5-di-tert-butylsalicylaldehyde $(1 \mathrm{~g})$ in ethanol (50 $\mathrm{mL})$ were mixed and refluxed at $80^{\circ} \mathrm{C}$ for 30 hours. The reaction mixture was cooled to the room temperature and filtered under vacuum. The synthesized material $(\mathrm{HL})$ was washed with ethanol in order to remove the unreacted chemicals and impurities. The obtained hybrid material was dried in air.

\section{Results And Discussion}

The graphene oxide (GO) was obtained from the powder graphite by the route of Hummer's method [21]. The sheets of GO are strongly hydrophilic and have some chemical and physical interactions between the layers and water molecules [21]. Graphite oxide can be completely exfoliated by simple sonication and by 
stirring the water/graphite oxide mixture for a long time in order to produce aqueous colloidal suspensions of graphene oxide sheets. After this processes, the surface of the obtained GO was chemically modified with 3-(trimethoxysilyl)propylamine (GO-APTMS) having a free amine group (- $\left.\mathrm{NH}_{2}\right)$ on the surface of GO. Finally, the amine-modified GO-APTMS was reacted with 3,5-di-tertbutylsalicylaldehyde to give the final hybrid material $(\mathrm{HL})$.

\subsection{Electronic properties of the graphene oxide (GO)}

The UV-vis spectrum of GO in the aqueous dispersion is shown in Fig.1. Characteristic two absorption bands were observed in the spectrum of GO. A shoulder seen at $\sim 310 \mathrm{~nm}$ corresponds to the $n-\pi^{*}$ transitions. The second characteristic band appeared at $237 \mathrm{~nm}$ can be attributed to the $\pi-\pi^{\star}$ transitions of the aromatic $\mathrm{C}=\mathrm{C}$ bonds which corresponds to the $\mathrm{sp}^{3}$ character in $\mathrm{GO}$ [20-23].

\subsection{FT-IR}

FT-IR spectra of the GO and hybrid material HL are given in Fig. 2. In the FTIR spectrum of GO, the broad peak at $3452 \mathrm{~cm}^{-1}$ comes from $\mathrm{O}-\mathrm{H}$ vibrations of the $-\mathrm{COOH}$ and $-\mathrm{OH}$ groups located on the surface of the GO. The vibration peak at $2926 \mathrm{~cm}^{-1}$ is corresponded to aliphatic $\mathrm{C}-\mathrm{H}$ stretching modes. The peak at the $1729 \mathrm{~cm}^{-1}$ can be attributed to the carbonyl $(C=0)$ stretching band. In addition, the aromatic $\mathrm{C}=\mathrm{C}$ vibrations were shown at the $1630 \mathrm{~cm}^{-1}$.

In FT-IR spectra of the obtained GO-APTMS, the vibration band at $3435 \mathrm{~cm}^{-1}$ can be attributed to $0-\mathrm{H}$ stretching mode. A weak peak at $1573 \mathrm{~cm}^{-1}$ was the stretch of $\mathrm{NH}_{2}$ groups which confirmed the successful grafting of APTMS to GO. The peak at $2930 \mathrm{~cm}^{-1}$ can be attributed to aliphatic C-H vibrations of the methylene in APTMS moiety and aliphatic groups on GO. The bending bands at 1118 and 1053 $\mathrm{cm}^{-1}$ may be assigned to the vibrations of $\mathrm{Si}-\mathrm{O}-\mathrm{Si}$ and $\mathrm{Si}-\mathrm{O}-\mathrm{C}$, respectively. In the spectrum of the hybrid material $(\mathrm{HL})$, there are two characteristic bands at 1115 and $1048 \mathrm{~cm}^{-1}$. The peak at $1632 \mathrm{~cm}^{-1}$ can be attributed to the azomethine group $\mathrm{CH}=\mathrm{N}$.

\subsection{SEM and EDX}

The EDX spectra of GO, GO-APTMS and HL materials are given in Fig. 3a-c. In EDX spectrum of GO (Fig. $3 a)$, three elements $C(70.35 \%), O(28.68 \%)$ and $S(0.97 \%)$ were calculated in its ingredient. The very small amount of sulfur gradients in the syntheses may come from sulfuric acid used in the preparation reaction of the GO by Hummer's method (Fig. 3b and 3c). The elemental compositions of GO-APTMS are $57.03 \%$ C, $29.12 \% 0,7.39 \% \mathrm{Si}, 6.34 \% \mathrm{~N}$ and $0.12 \% \mathrm{~S}$ calculated in the EDX spectrum of GO-APTMS. According to the EDX spectra of GO-APTMS, it can be said that 3-(trimethoxysilyl) propylamine was attached on the surface of the GO. The compositions of the elements of $\mathrm{HL}$ are $61.83 \% \mathrm{C}, 24.40 \% \mathrm{O}, 6.94 \% \mathrm{Si}, 6.38 \% \mathrm{~N}$ 
and $0.45 \% \mathrm{~S}$ calculated in the EDX spectrum of the material $\mathrm{HL}$. While the percentages of $\mathrm{C}$ and $\mathrm{N}$ increasing, the percentages of the other elements decreased confirming the modification on the surface.

The scanning electron microscope (SEM) images of GO, GO-APTMS and HL materials were given in Figs. $4 \mathrm{a}$ and $4 \mathrm{~b}$. According to the SEM images, the individual GO sheets were found to have a thickness of 100 $\mathrm{mm}$ that much larger than the thickness of single layer graphene. This increase in the thickness is due to the introduction of the oxygen-containing functional groups. It can also be noted that the $\mathrm{GO}$ sheets were thicker at the edges. This is because the oxygen-containing functional groups were mainly combined at the edges and the surface of GO. GO sheets were firmly suspended and did not bend according to the SEM images. However, SEM image of HL (Fig. 4b) reveals the extended sheets of lateral dimensions in the length of $1 \mathrm{~mm}$. On the other hand, SEM image displays two-dimensional crumpled nano-sheets with a few stacked layers

\subsection{XRD and TEM}

The structural changing of $\mathrm{GO}$ to $\mathrm{HL}$ were observed from X-ray diffraction patterns as in (Fig. 5a,b). The sharp diffraction peak at $2 \theta=9.45^{\circ}(\mathrm{d}=0.935 \mathrm{~nm})$ and narrow small peak at $2 \theta=44.5524^{\circ}$ correspond to the spacing of the $\mathrm{GO}$ in the plane (Fig. 5a). After the synthesis of APTMS-GO, while disappearing the sharp peak of GO, a new sharp peak revealed at $2 \theta=6.2^{\circ}(d=1.42 \mathrm{~nm})$. The other new broader and weaker diffraction peaks appeared at $2 \theta=10.95^{\circ}(d=0.19 \mathrm{~nm})$ and $22.13^{\circ}(\mathrm{d}=0.4 \mathrm{~nm})$ indicated that the attachment of the functional silane groups occurred successfully on the surface of GO nano-sheets. In XRD pattern (Fig. 5 b) of $\mathrm{HL}$, the sharp diffraction peak at $2 \theta=10.5274^{\circ}$ belongs to the graphene oxide. The weak peaks at 45.0124 and $51.4285^{\circ}$ can be attributed to the bonded compounds in the hybrid material.

The morphological structures of the materials GO, APTMS-GO and HL were also characterized by transmission electron microscope (TEM) (Figs. 6a-c). The elastic corrugations and the scrolled or folded edges often result in different brightness on the surface of the GO (Fig. 6a). The results indicate that GO has a high surface area and is a mesoporous material. The mesoporous structure and low surface area may be due to the agglomerations of GO sheets during the drying treatment because of the van der Waals forces between each single sheet of GO. In TEM image (Fig. 6b) of APTMS-GO, the black dots on the surface of the $\mathrm{GO}$ can be attributed to the amino silane groups. The TEM image of the hybrid material was taken at $0.2 \mathrm{~mm}$. In the hybrid material (Fig. 6c), several black aggregations on the surface of the GO-APTMS may be assigned to the imine group.

\subsection{Thermal Properties}

Thermal properties of all the materials were analyzed by thermogravimetric (TGA) and differential thermal analyses techniques (DTA) under $\mathrm{N}_{2}$ atmosphere in the range of $20-900{ }^{\circ} \mathrm{C}$. Thermal curves of the materials have given in Figs. 7k-n. In TGA curve of the powder graphite, the adsorbed water molecules 
desorbed between $50-100^{\circ} \mathrm{C}$. The absorbed water molecules and the degradation of some substituents were lost in the $100-200{ }^{\circ} \mathrm{C}$ temperature range. After this temperature range, the mass loss of the graphite continues up to $850^{\circ} \mathrm{C}$ (Fig. 7a) with the degradation of organic backbone. In TGA curve of the graphene oxide (Fig. $7 \mathrm{~b}$ ), the adsorbed water molecules are move away in $40-50^{\circ} \mathrm{C}$ range.

Organo-silanized substituents and absorbed water were decomposed up to $200^{\circ} \mathrm{C}$ in the thermal curve of the GO-APTMS (Fig. 7c). Decomposition of the organic backbone continued up to $900^{\circ} \mathrm{C}$. The TG/DTA/DTG curves of the hybrid material (Fig. 7d) showed that the decomposition process occurs at four steps. At first and second steps, the adsorbed and decomposed water molecules from the substituents such as silanol and oxygen containing structures. At the other steps, the organic parts of the material $\mathrm{HL}$ decomposed continued up to $800^{\circ} \mathrm{C}$. The thermal stability of the hybrid material is lower than the other graphene derivatives.

\subsection{Adsorption-Desorption and Isotherms}

The hybrid material ( $\mathrm{HL})$ was used as adsorbents for the removal of $\mathrm{Zn}(\mathrm{II})$ and $\mathrm{Co}(\mathrm{II})$ cations from aqueous solutions. For the adsorption measurements, the aqueous solutions of $\mathrm{Zn}$ (II) or Co(II) (25 ppm, $25 \mathrm{~mL}$ ) were mixed with the hybrid material $(\mathrm{HL})$ at room temperature as a batch process. At the end of each experiment, HL was filtered, and the metal content was analyzed with ICP-OES. The results were given as the average of the replicates. The effect of $\mathrm{pH}$, concentration, contact time and temperature on the adsorption capacity of the hybrid material $(\mathrm{HL})$ were explored. The amount of metal ions adsorbed per unit mass of the hybrid material $(\mathrm{HL})$, maximum absorption capacity $\mathrm{Q}(\mathrm{mg} / \mathrm{g})$ was determined by the following equation (Eq. 1)

$Q=\left[\left(C_{0}-C\right) \cdot V\right] / m(1)$

where $\mathrm{C}_{0}$ and $\mathrm{C}(\mathrm{mg} / \mathrm{L})$ are the liquid-phase concentrations of metals before and after adsorption respectively. $V$ is the volume of the solution $(L)$ and $m$ is the mass of hybrid material $(\mathrm{HL})$.

\subsection{Effect of $\mathrm{pH}$}

The maximum adsorptions were provided at $\mathrm{pH}=9$ for $\mathrm{Zn}$ (II) $(24.624 \mathrm{mg} / \mathrm{g})$ and $\mathrm{Co}(\mathrm{II})(23.766 \mathrm{mg} / \mathrm{g})$. During the adsorption process, the oxygen-containing functional groups on the surface of the hybrid material are formed anionic layer with $\mathrm{H}^{+}$ions releasing in the solution. The adsorption of $\mathrm{Zn}$ (II) and $\mathrm{Co}$ (II) is gradually subjected to ion exchange with the hydrogen cation on the surface of hybrid material $(\mathrm{HL})$ when $\mathrm{pH}$ are increased $[22,23]$. The effect of $\mathrm{pH}$ on the adsorption is shown in Fig. 8.

\subsection{Effect of contact time}


The effect of the reaction time on the adsorption capacity of the hybrid material $(\mathrm{HL})$ was also investigated at $\mathrm{pH}=9$ in the 0-120 min. range. The dependence on time is shown in Fig. 9. For both $\mathrm{Co}(\mathrm{II})$ and $\mathrm{Zn}(\mathrm{II})$, the adsorption rate is extremely high for the first $10 \mathrm{~min}$ with the adsorption of 21.26 and $23.12 \mathrm{mg} / \mathrm{g}$, respectively. The adsorption capacity of $\mathrm{HL}$ for $\mathrm{Co}(\mathrm{II})$ reaches a maximum at $50 \mathrm{~min}$ with $24.951 \mathrm{mg} / \mathrm{g}$ and remains constant. The maximum absorption occurs at $70 \mathrm{~min}$ with $24.762 \mathrm{mg} / \mathrm{g}$ for $\mathrm{Zn}(\mathrm{II})$. The adsorption equilibrium is mainly due to high geometrical affinity between heavy metal ions and functional hybrid material. The slightly faster adsorption of Co(II) may be better coordination interactions between the $\mathrm{HL}$ and metal ion.

\subsection{Effect of the initial metal concentration on the adsorption capacity}

Effect of the initial metal concentration on the adsorption capacity was investigated at $\mathrm{pH}=9$ for a period of $50 \mathrm{~min}$ for Co(II) and $70 \mathrm{~min}$ for Zn(II) (Fig. 10). The adsorption capacity of HL presents an increasing trend with concentration increasing. The maximum adsorption occurs at $691.004 \mathrm{ppm}$ for $\mathrm{Zn}$ (II) and $623.786 \mathrm{ppm}$ for $\mathrm{Co}$ (II) and remains almost constant above these concentrations. The concentration increase results in a slightly better adsorption for Zn(II).

\subsection{Effect of Temperature}

The effect of temperature on the adsorption capacity was investigated in the $0-60{ }^{\circ} \mathrm{C}$ range (Fig. 11). Until $25^{\circ} \mathrm{C}$, the sharp adsorption increase was observed for $\mathrm{Zn}(\mathrm{II})$ and $\mathrm{Co}(\mathrm{II})$ ions. The maximum adsorptions were obtained at 24.92 and $24.37^{\circ} \mathrm{C}$ for $\mathrm{Zn}$ (II) and Co(II), respectively. In the $20-60{ }^{\circ} \mathrm{C}$ range, there is no considerable change in the adsorption capacity of the $\mathrm{HL}$.

\subsection{Reusability of the adsorbent}

Regeneration process is very important in the industry. The reusability of the hybrid material was investigated 10 times. The obtained results are given in Fig. 12. After each experiment, the adsorbed metal ions were removed from the $\mathrm{HL}$ by using $\mathrm{HNO}_{3}(4 \mathrm{M})$ as the desorption agent. According to the adsorption capacity of the hybrid material for each cycle, the organo-silanized hybrid material showed effective adsorption properites up to seven times (Fig. 12). After seven times using, the adsorption capacity of the hybrid material decreased suggesting the deformation of the HL.

\subsection{Analysis of real samples and analytical performance of the method}


The standard addition methods were used for the removal of Co(II) and Zn(II) ions from drinking water samples by the hybrid material. The internal standard addition method by spiking the samples with Co(II) and $\mathrm{Zn}$ (II) ions in the fixed concentrations were used. The obtained results were given in Table 1 . The recovery performance of was obtained as $98.65-101.75 \%$ for $Z n(I I)$ adsorption while $98.55-104.0 \%$ for $\mathrm{Co}(\mathrm{II})$. The results showed that there is a good correlation between the values obtained and approved. The analytical performance data for the pre-concentration studies for $\mathrm{Co}$ (II) and $\mathrm{Zn}$ (II) ions are listed in Table 2. The obtained data indicate that the $\mathrm{Co}(\mathrm{II})$ and $\mathrm{Zn}$ (II) ions can be detected as low concentration as 2.13 and $3.43 \mathrm{ng} / \mathrm{mL}$, respectively. The precision of the method was found as $1.9 \%$ for $\mathrm{Zn}$ (II) and $3.8 \%$ for $\mathrm{Co}(\mathrm{II})$. In the preconcentration studies, a linear curve was observed in the range of $0.7-26.0 \mathrm{ng} / \mathrm{mL}$ for $\mathrm{Zn}(\mathrm{II})$ and 0.5-22 ng/mL for Co(II). The enrichment factor was found as $441 \mathrm{for} \mathrm{Zn}(\mathrm{II})$ and 675 for $\mathrm{Co}$ (II).

Table 1. Determination of $\mathrm{Zn}(\mathrm{II})$ and $\mathrm{Co}(\mathrm{II})$ ions in real water samples by standard addition methods.

\begin{tabular}{|c|c|c|c|c|c|c|}
\hline \multirow[t]{4}{*}{ Samples } & \multicolumn{2}{|c|}{$\begin{array}{l}\mathrm{Zn}(\mathrm{II}) \\
\left(\mathrm{mg} \cdot \mathrm{L}^{-1}\right)\end{array}$} & \multirow[t]{2}{*}{ Recovery (\%) } & \multicolumn{2}{|c|}{$\begin{array}{l}\text { Co(II) } \\
\left(\mathrm{mg} \cdot \mathrm{L}^{-1}\right)\end{array}$} & \multirow[t]{2}{*}{ Recovery (\%) } \\
\hline & Added & Found & & Added & Found & \\
\hline & 0.00 & nd & - & 0.00 & nd & - \\
\hline & 20.00 & $20.28 \pm 0.9^{a}$ & 101.40 & 20.00 & $20.80 \pm 0.36$ & 104.00 \\
\hline \multirow[t]{4}{*}{ Certified Water } & 40.00 & $39.46 \pm 0.7$ & 98.65 & 40.00 & $39.42 \pm 0.49$ & 98.55 \\
\hline & 60.00 & $61.05 \pm 0.3$ & 101.75 & 60.00 & $61.73 \pm 0.86$ & 102.88 \\
\hline & 80.00 & $80.73 \pm 0.5$ & 100.91 & 80.00 & $80.09 \pm 0.05$ & 100.11 \\
\hline & 0.00 & nd & - & 0.00 & nd & - \\
\hline Tap Water & 20.00 & $20.02 \pm 0.70$ & 100.10 & 20.00 & $20.37 \pm 0.95$ & 101.85 \\
\hline \multirow[t]{3}{*}{ (Drinking Water) } & 40.00 & $40.67 \pm 1.20$ & 101.67 & 30.00 & $30.72 \pm 1.02$ & 100.54 \\
\hline & 60.00 & $60.98 \pm 1.23$ & 101.63 & 60.00 & $61.07 \pm 0.65$ & 101.78 \\
\hline & 80.00 & $81.01 \pm 0.98$ & 101.26 & 80.00 & $80.70 \pm 0.76$ & 100.87 \\
\hline
\end{tabular}

nd: not detected; a: meanvalue \pm standart deviation based on three replicate measurements.

Table 2. Performance characteristic of preconcentration procedure. 


\begin{tabular}{|lll|}
\hline Parameters & $\mathrm{Zn}(\mathrm{II})$ & $\mathrm{Co}(\mathrm{II})$ \\
\hline Precision (R.S.D.) & $1.9 \%$ & $3.8 \%$ \\
\hline Detection limit (3s) & $2.13 \mathrm{ng} / \mathrm{mL}$ & $3.43 \mathrm{ng} / \mathrm{mL}$ \\
\hline Linear calibration range & $0.7-26.0 \mathrm{ng} / \mathrm{mL}$ & $0.5-22.0 \mathrm{ng} / \mathrm{mL}$ \\
\hline $\begin{array}{l}\text { Reg. equation (after } \\
\text { preconc.) }\end{array}$ & $\mathrm{AA}=0.0019 \mathrm{Zn}(\mathrm{II})+0.0008$ & $\mathrm{AA}=0.0025 \mathrm{Co}(\mathrm{II})-0.0003 \mathrm{ng} / \mathrm{mL}$ \\
\hline Con. regression equation & $\mathrm{AA}=0.0034 \mathrm{Zn}(\mathrm{II})+0.0043$ & $\mathrm{AA}=0.0049 \mathrm{Co}(\mathrm{II})+0.0037 \mu \mathrm{g} / \mathrm{mL}$ \\
\hline Enrichment factor & $\mu \mathrm{mg} / \mathrm{mL}$ & \\
\hline & $\begin{array}{l}0.0019 \\
\mathrm{ng} / \mathrm{mLx} 1000 \mu \mathrm{g} / \mathrm{mL} / 0.0043=441\end{array}$ & $0.0025 \mathrm{ng} / \mathrm{mL} \mathrm{x}$ \\
\hline
\end{tabular}

\subsection{Langmuir adsorption isotherms}

The adsorption isotherms were used to investigate the interaction types between the adsorbents and metal ions. Possible interaction between the hybrid material $(\mathrm{HL})$ and the metal ions [Zn (II) or Co (II)] is in the form of coordinated-covalent bonding. Therefore, it fits with Langmuir adsorption model. The model suggests that the molecules or ions are adsorbed at a fixed number of well-defined sites. During the batch experiments, the Langmuir adsorption isotherm was used to evaluate adsorption properties. Eq. (2) expresses the Langmuir adsorption isotherm:

\section{$C_{e q} / Q=1 /\left(Q_{\max } \times b\right)+C_{e q} / Q_{\max }$}

where $\mathrm{q}$ is the adsorbed amount of $\mathrm{Zn}$ (II)or $\mathrm{Co}(\mathrm{II})(\mathrm{mg} / \mathrm{g})$, Ceq the equilibrium $\mathrm{Zn}$ (II)/Co(II) concentration $(\mathrm{mg} / \mathrm{mL}), b$ the Langmuir constant $(\mathrm{mL} / \mathrm{mg})$, and $Q_{\max }$ is the maximum desorption capacity $(\mathrm{mg} / \mathrm{g})$. Fig. 13 and Table 3 illustrate the equilibrium constants of Langmuir isotherm. The correlation coefficients of Langmuir isotherm $\left(\mathrm{R}^{2}\right)$ were determined as 0.9841 for $\mathrm{Zn}(\mathrm{II})$ and 0.998 for $\mathrm{Co}(\mathrm{II})$. The experimental and theoretical maximum adsorption values show a good correlation between each other (Table 3 ).

Table 3. Langmuir adsorption constants for the hybrid material.

\begin{tabular}{|c|c|c|c|c|}
\hline & Experimental & Langmuir col & tans & \\
\hline $\mathrm{HL}$ & $\mathrm{Q}_{\max }(\mathrm{mg} / \mathrm{g})$ & $\mathrm{Q}_{\max }(\mathrm{mg} / \mathrm{g})$ & $b$ & $\mathrm{R}^{2}$ \\
\hline $\mathrm{Zn}(\mathrm{II})$ & 627.963 & 633.347 & 3.2 & 0.9841 \\
\hline $\mathrm{Co}(\mathrm{II})$ & 691.004 & 587.6785 & 2.4 & 0.998 \\
\hline
\end{tabular}




\section{Conclusion}

The imine-graphene hybrid material $(\mathrm{HL})$ was prepared and characterized by the FT-IR, XRD, EDX, SEM, TEM and UV-Vis. techniques. Thermal properties of HL were investigated by TGA/DTA methods in the 25$1000{ }^{\circ} \mathrm{C}$ temperature range. The hybrid material ( $\left.\mathrm{HL}\right)$ was used as adsorbent for the removal of $\mathrm{Co}(\mathrm{II})$ and $\mathrm{Zn}$ (II) from aqueous solutions using the batch process. The several parameters such as $\mathrm{pH}$, contact time, temperature, and concentration were applied to optimize the adsorption capacity of the hybrid material. The enrichment factor was found as 441 for $\mathrm{Zn}$ (II) and 675 for $\mathrm{Co}$ (II). The recovery performance of was obtained as $98.65-101.75 \%$ for Zn(II) adsorption while $98.55-104.0 \%$ for Co(II). The adsorption results suggest that the hybrid material $(\mathrm{HL})$ may have a potential usage as an adsorbent material for the detection and removal of $\mathrm{Co}(\mathrm{II})$ and $\mathrm{Zn}$ (II) ions.

\section{References}

1. J.A. Grout, C.D. Levings, Environ. Res., 51, 265(2001).

2. C. Lin, Y.Wu,W. Lu, A. Chen, Y. Liu., J. Hazard. Mater., 142, 199(2007).

3. X. Tang, Z. Li, Y. Chen, J. of Hazard. Mater., 161, 824(2009).

4. NRC (National Research Council), DrinkingWater and Public Health Safe Drinking Water Committee, vol. 1, National Academy Press, Washington, DC, (1977).

5. WHO, World Health Organization, Guidelines for drinking water quality., 1, 52(1993).

6. A. Netzer, D.E. Huges, Water Res., 18 (8), 927(1984).

7. L.L. Tavlaride, J.H. Bae, C.K. Lee., Sep. Sci. Technol., 22, 581(1987).

8. S. Karabulut, A. Karabakan, A. Denizili, Y. Yurum, Sep. Purif. Technol., 18, 177(2000).

9. P.A. Brown, S.A. Gill, S.J. Allen, Water Res., 34, 3907(2000).

10. M.I. Kandah, Sep. Purif. Technol., 35, 61(2004).

11. L. Prasanna, L. Janardhan R. Koduru, H. Roha, Y.-L. Choi, Y.Y. Chang, J.K. Yang, Hydrometallurgy., 165, 90(2016).

12. L.P, Lingamdinne, H. Roh, Y.L Choi, J.R. Koduru, J.K, Yang, Y.Y Chang, J. Ind. Eng. Chem., 32, 178(2015).

13. S. Zhang, Z. Guo, J. Xu, H. Niu, Z. Chen, J. Xu, J. Radioanal. Nucl. Chem., 288 (1), 121(2011).

14. A. Ahmadpour, M. Tahmasbi, T. Rohani Bastami, J. Amel Besharati, J. Hazard. Mater., 166, 925(2009).

15. A. Dell'Era, M. Pasquali, C. Lupi, F. Zaza, Hydrometallurgy., 150, 1(2014).

16. B. Krause, R.F, Sandenbergh, Hydrometallurgy., 155, 132(2015).

17. J. Mizera, G. Mizerova, V. Machovic, L. Borecka, Water Res., 41, 620(2007).

18. J. Oliva, J.D, Pablo, J.L. Cortina, J. Cama, C. Ayora, J. Hazard. Mater., 194, 312(2011).

19. X. Wang, Y. Guo, L. Yang, M. Han, J. Zhao, X. Cheng, Environ. \& Anal. Toxicol., 2, 1(2012). 
20. R. Rahimi, R.Z. Dorabei, A. Koohi, S. Zargari, , Iran University of Science and Technology, Tehran 16846-1311

21. WS. Hummersand, R. E. Offeman, J. Am. Chem. Soc., 80, 1339(1958).

22. S. Wu, X. Zhao, Y. Li, Q. Du, J. Sun, Y. Wang, X. Wang , Y. Xia, Z. Wang and L. Xia, Materials., 6, 2026(2013).

23. A. Joaquín, E. G. María, L. V. Lidia, J. P.Guillermo, Copello,Cátedra de Química Analítica Instrumental, Facultad de Farmacia y Bioquímica, Universidad de Buenos Aires (UBA), IQUIMEFA (UBA-CONICET), Junín 956, C1113AAD CABA, Argentina.

\section{Figures}

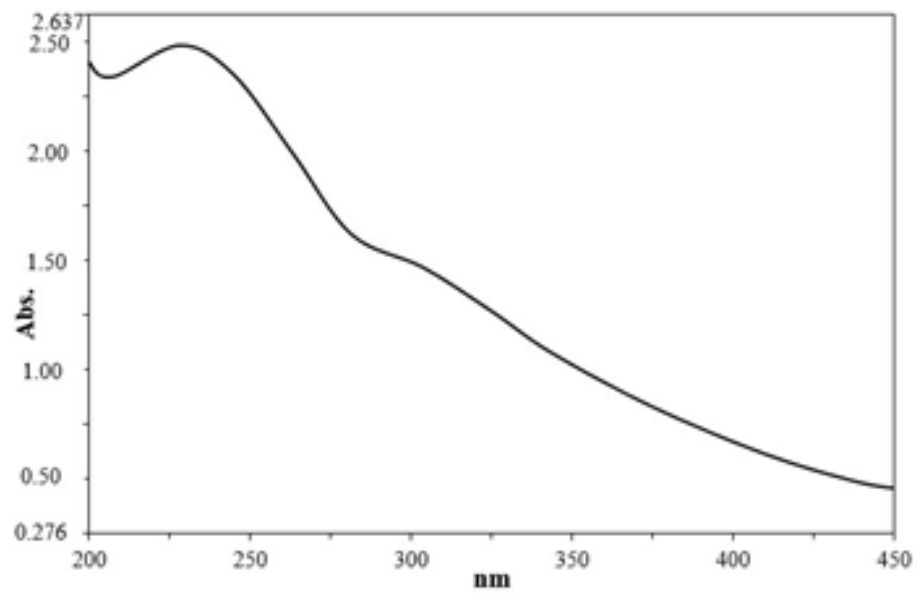

Figure 1

UV-Vis. spectrum of graphene oxide (GO).

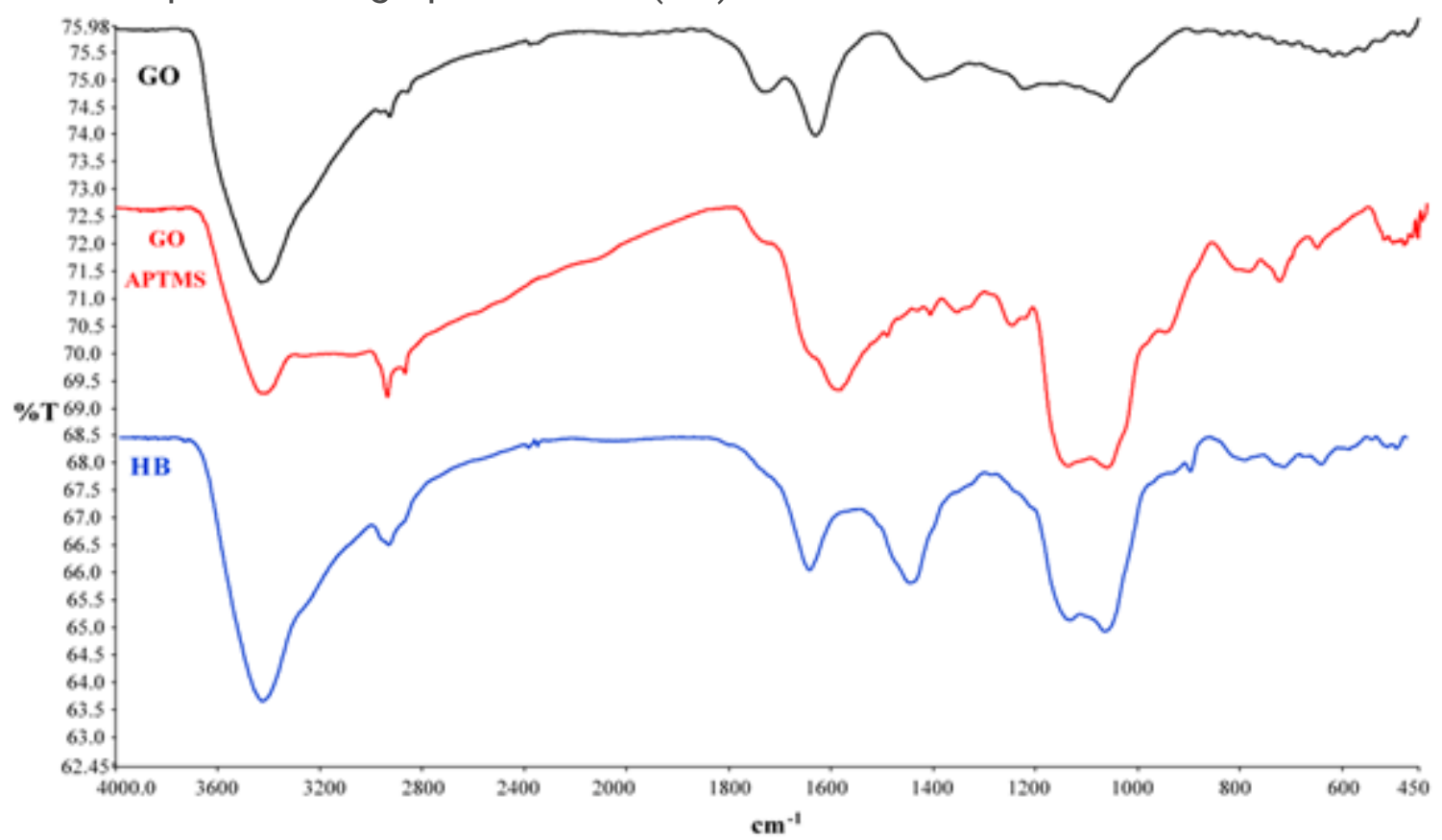


Figure 2

FT-IR spectra of the materials.

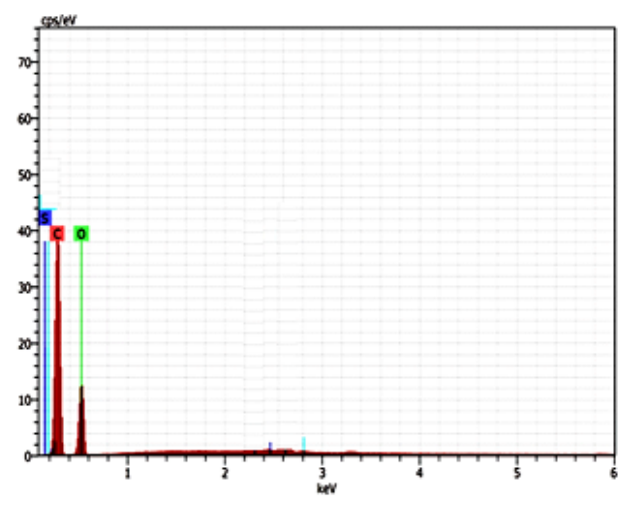

a) $\mathrm{GO}$

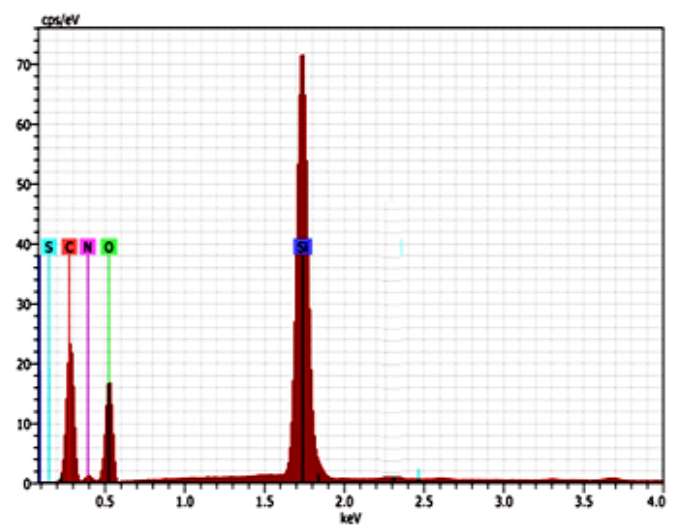

a) GO-APTMS

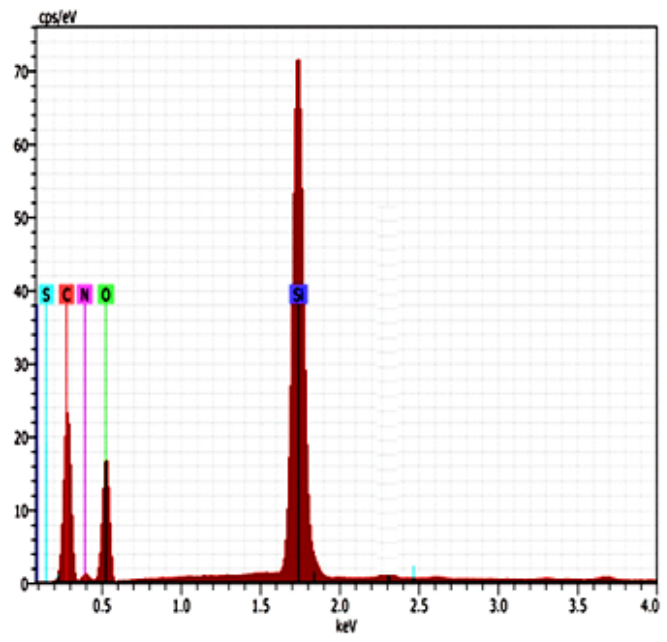

b) $\mathrm{M}$

Figure 3

EDX spectra of GO, GO-APTMS and M. 


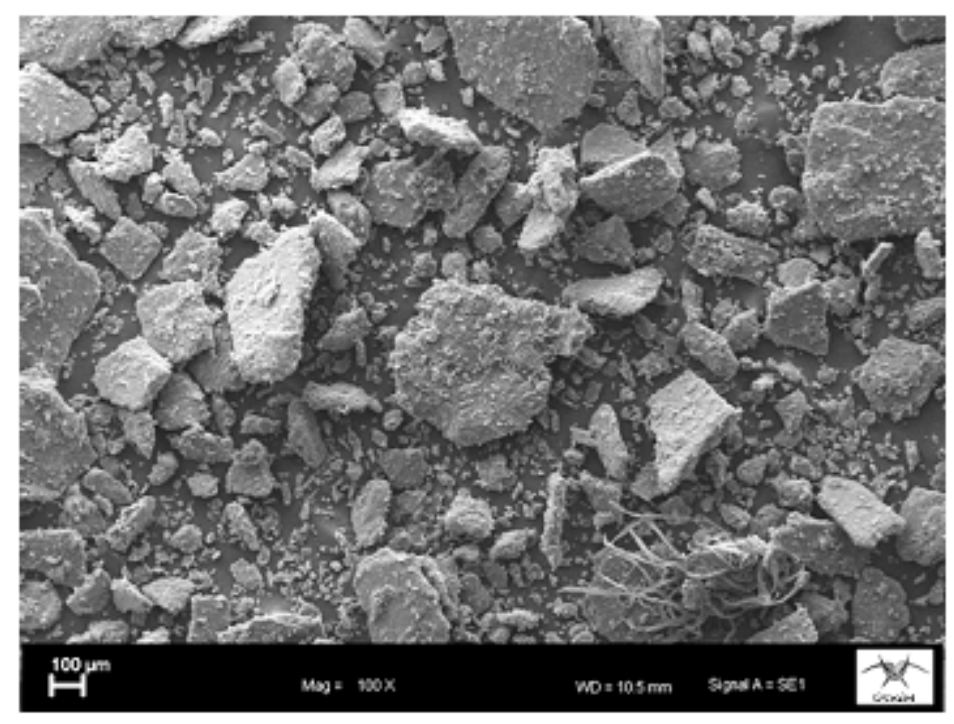

a) $\mathrm{GO}$

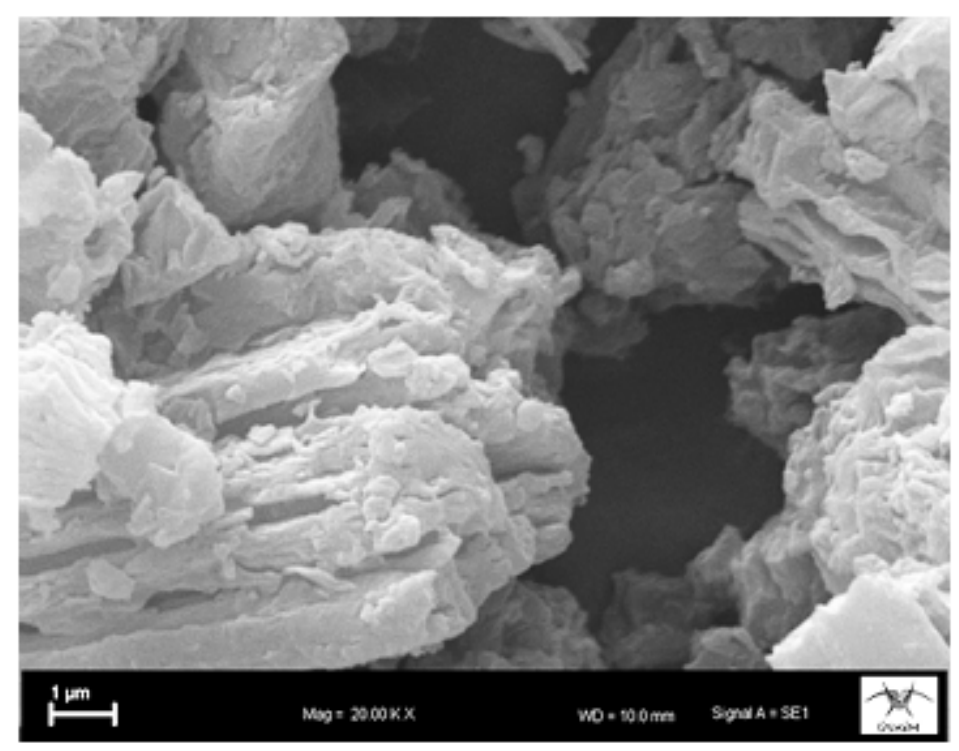

b) SEM image of HM

Figure 4

SEM imgaes of GO and HM 


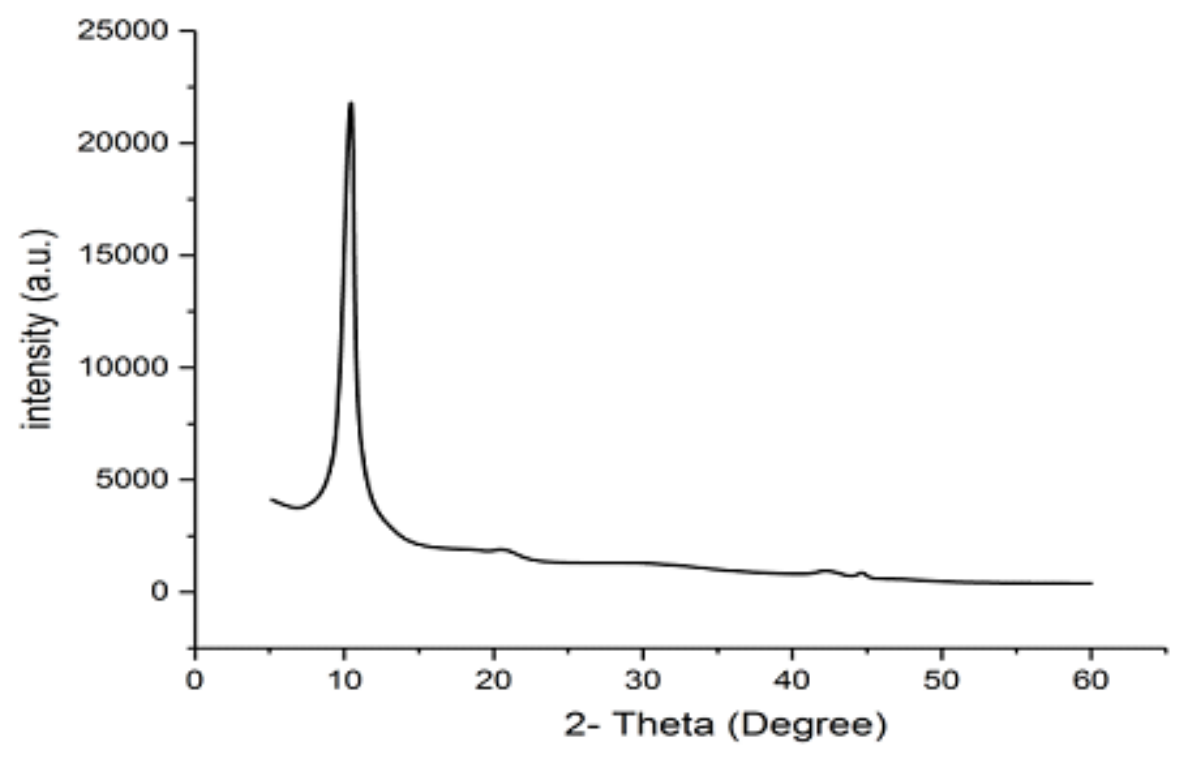

a) $\mathrm{GO}$

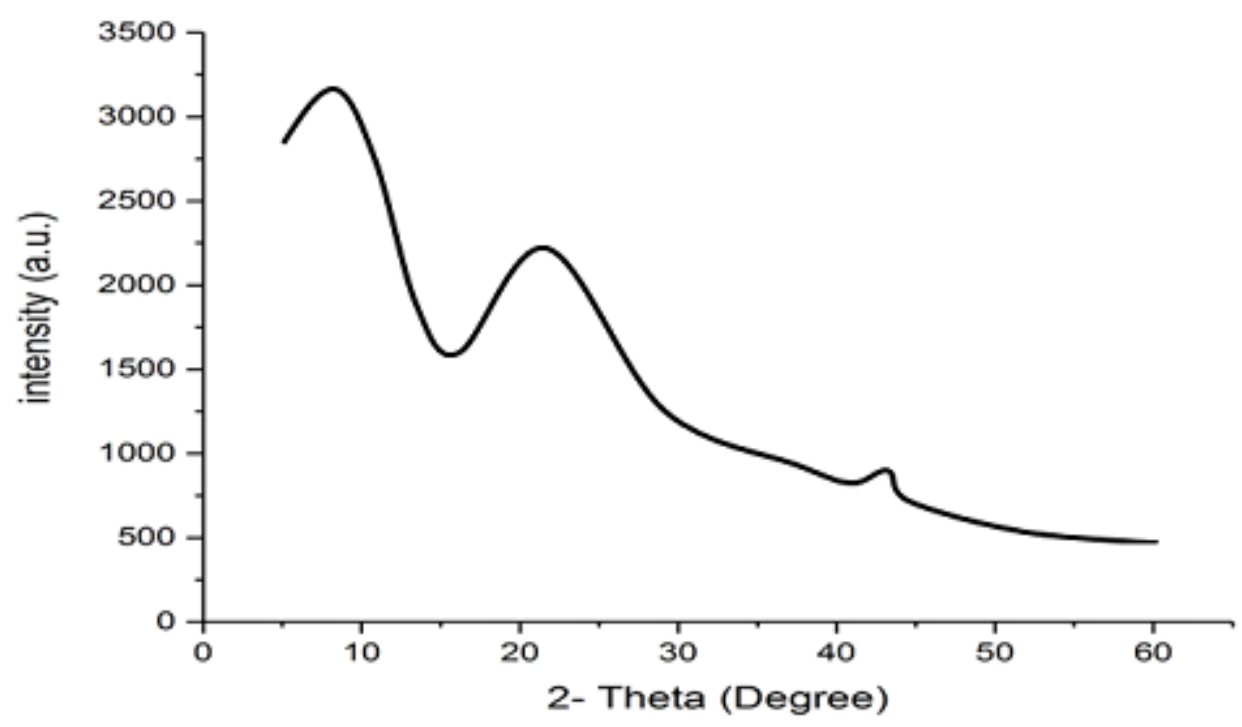

b) $\mathrm{HB}$

Figure 5

XRD patterns of the GO (a) and hybrid material (b). 


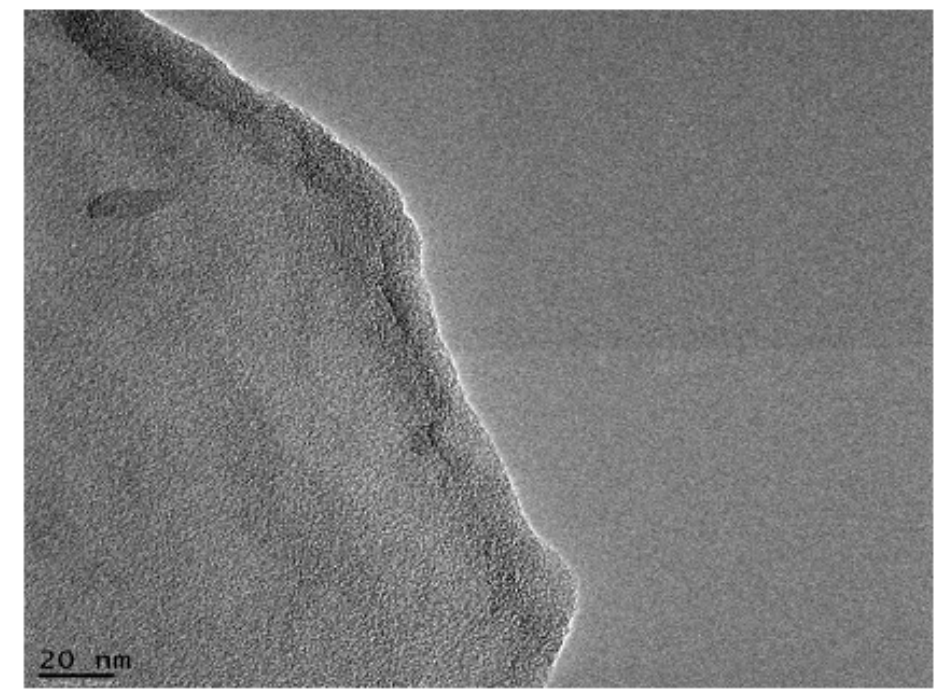

a) $\mathrm{GO}$

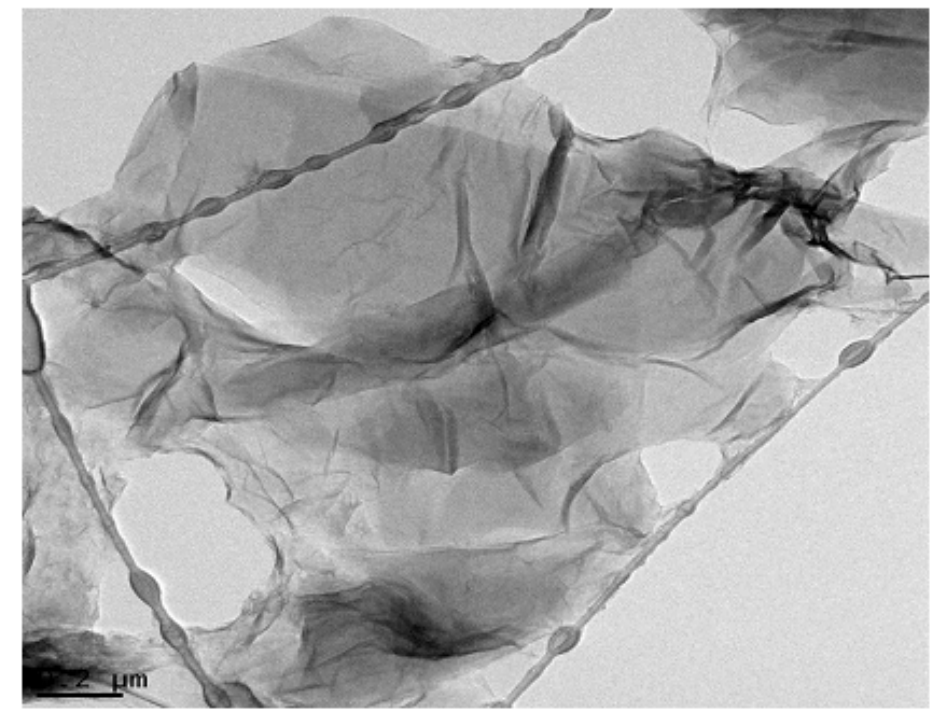

b) GO-APTMS

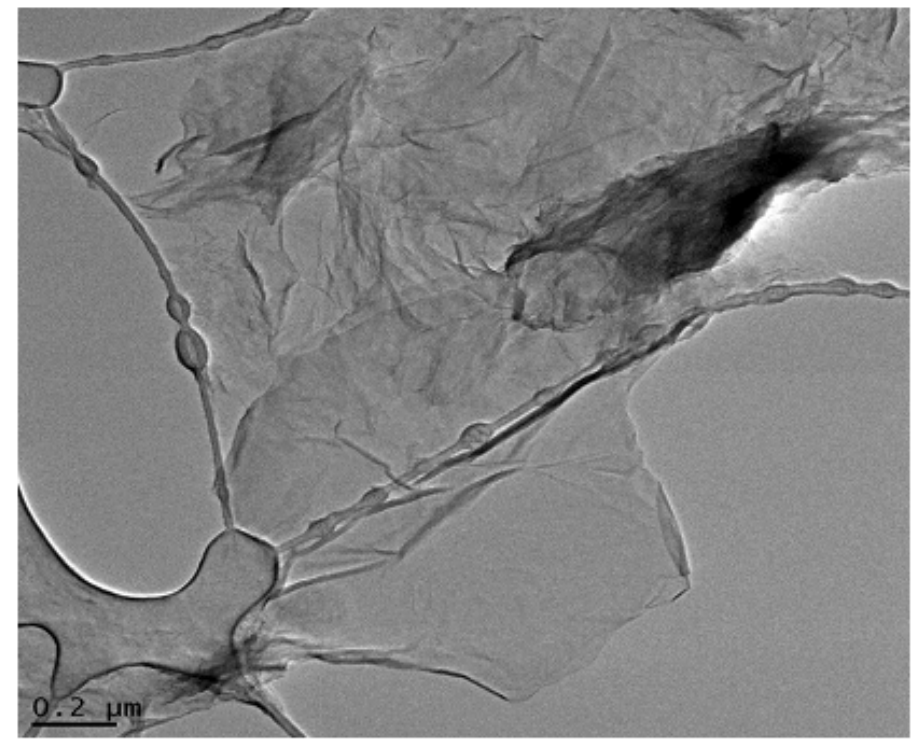

c) $\mathrm{HB}$

\section{Figure 6}

TEM imagings of the GO (a), GO-APTMS (b) and hybrid material (c). 


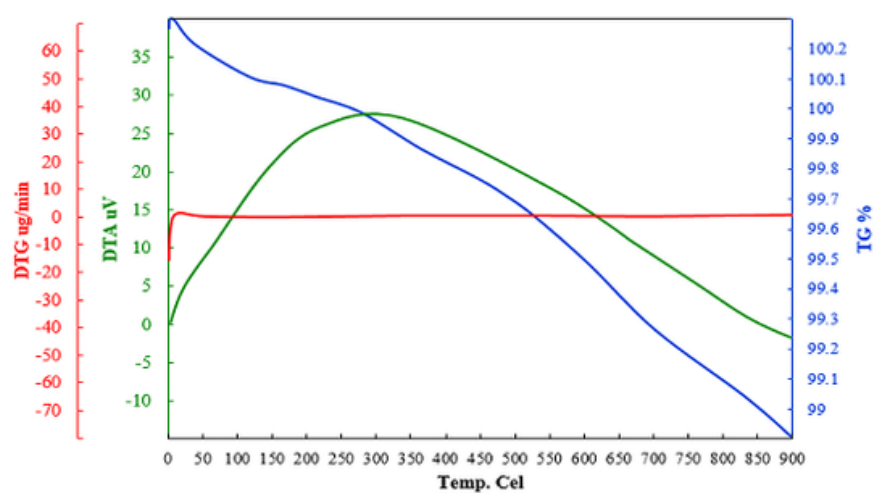

a) Graphite

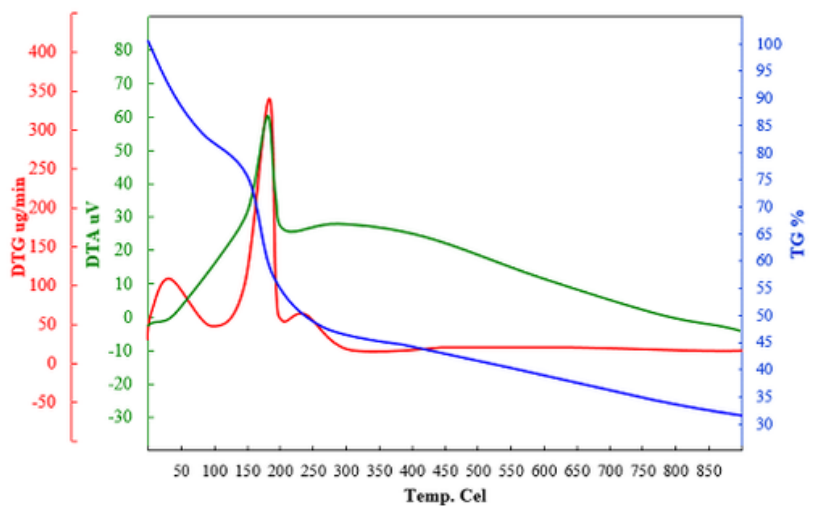

b) $\mathrm{GO}$

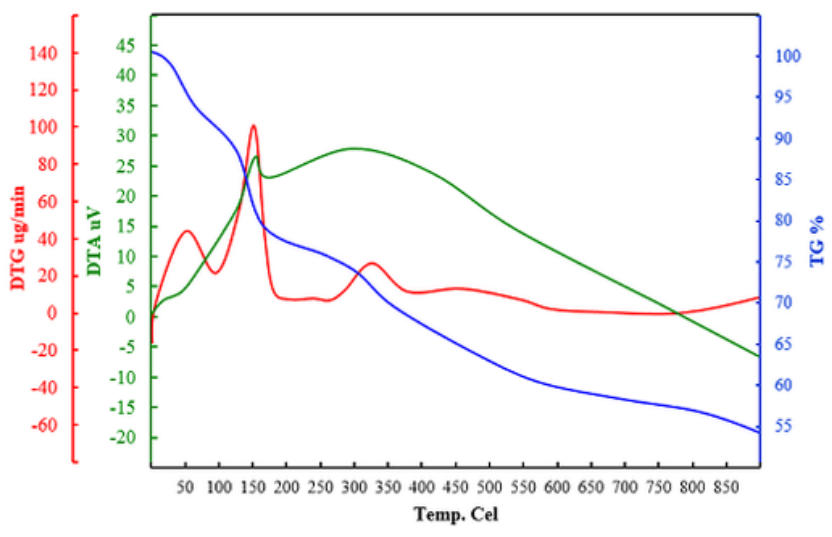

a) GO-APTMS

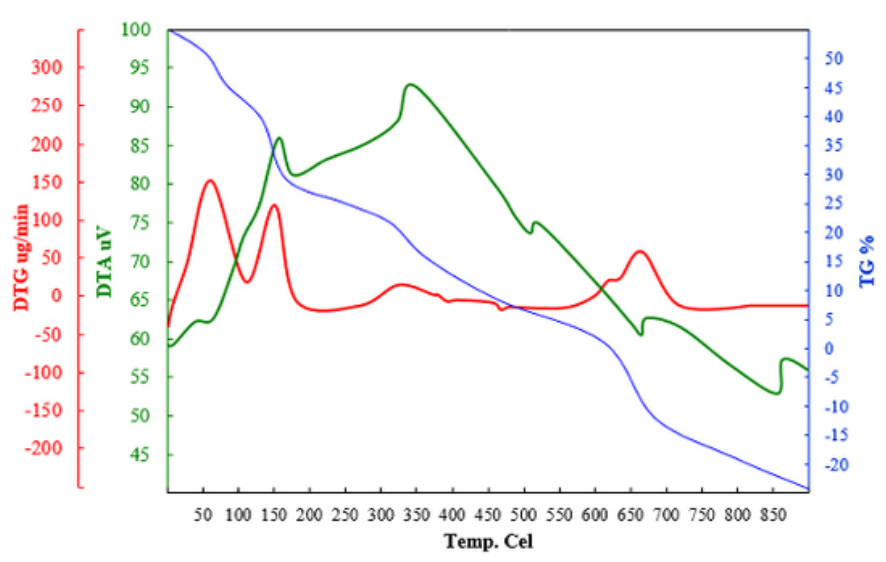

d) $\mathrm{HM}$

\section{Figure 7}

Thermal (TGA, DTA, DTG) curves of the graphite, GO, GO-APTMS and HM material in 20-900 \C range.

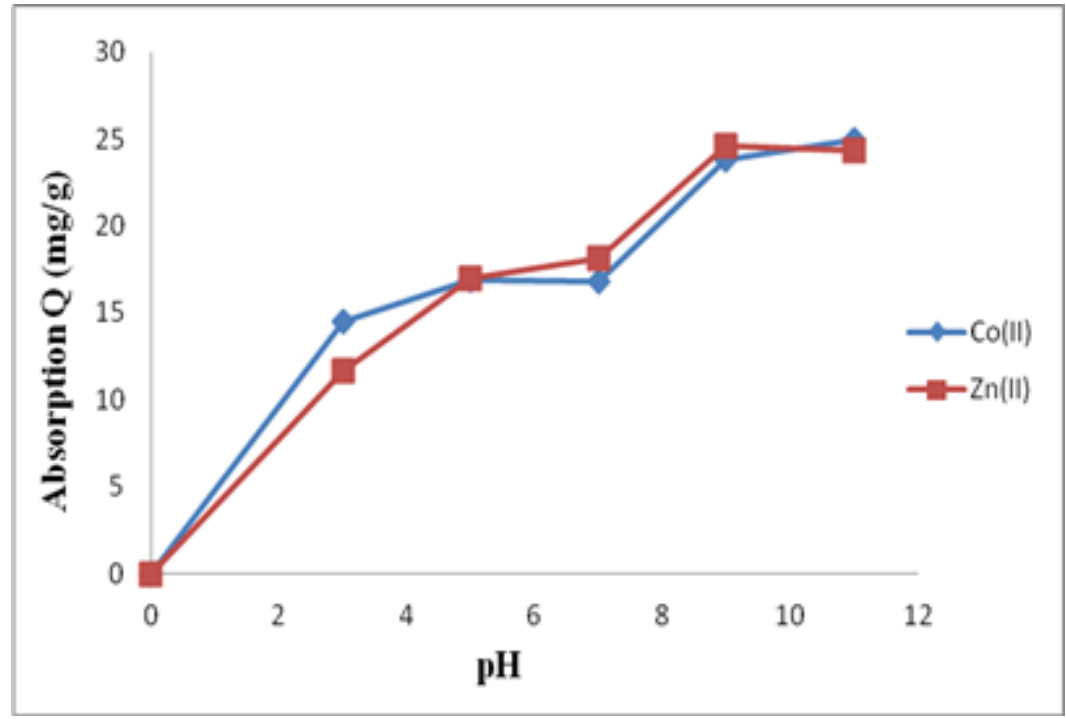

Figure 8

Effect of pH on Zn (II) and Co (II) adsorption. 


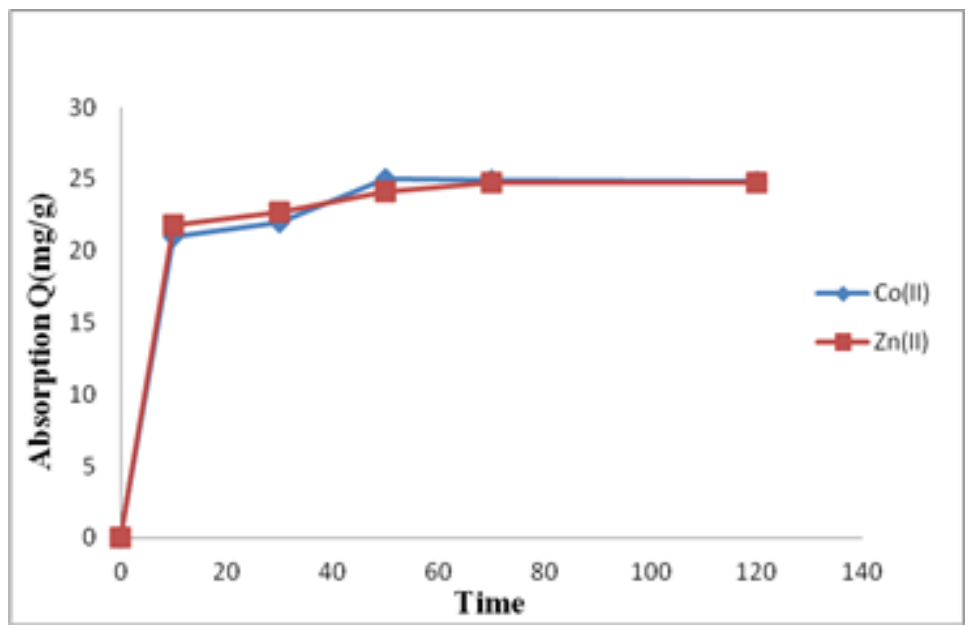

Figure 9

Effect of time on $\mathrm{Zn}$ (II) and $\mathrm{Co}$ (II) absorption; at $\mathrm{pH}=9 ; \mathrm{T}=25 \mathrm{oC}, 25 \mathrm{mg} / \mathrm{L}$, each point is an average of three parallel studies.

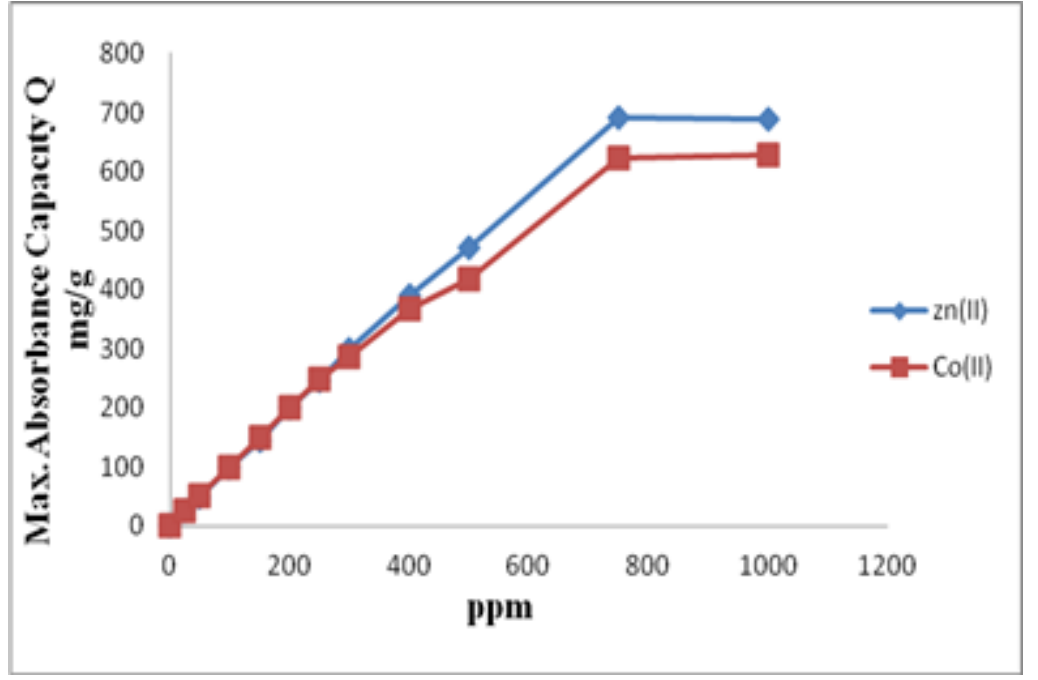

Figure 10

Effect of the initial metal concentration on the adsorption capacity; $\mathrm{pH}=9, \mathrm{~T}=25^{\circ} \mathrm{C}, 50 \mathrm{~min}$. for $\mathrm{Co}(\mathrm{II})$ and 70 min. for $\mathrm{Zn}(\mathrm{II})$, each point is an average of three parallel studies. 


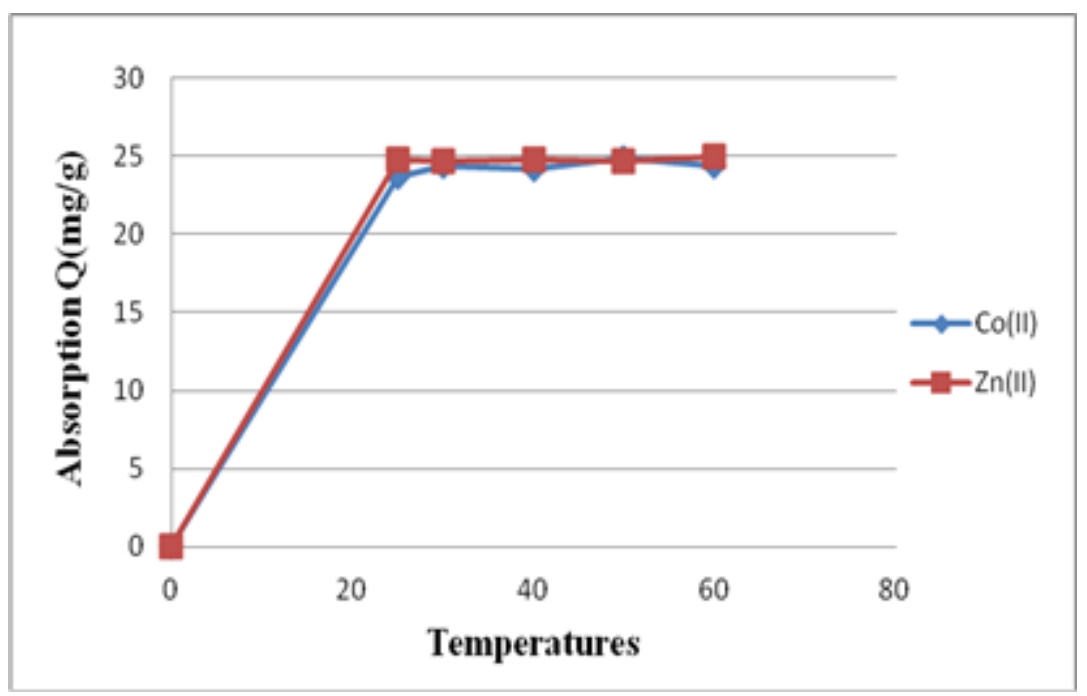

Figure 11

Effect of temperature on $\mathrm{Zn}(\mathrm{II})$ and $\mathrm{Co}(\mathrm{II})$ adsorption; concentration $25 \mathrm{mg} / \mathrm{L}, \mathrm{pH}=9,60 \mathrm{~min}$, each point is an average of three parallel studies.

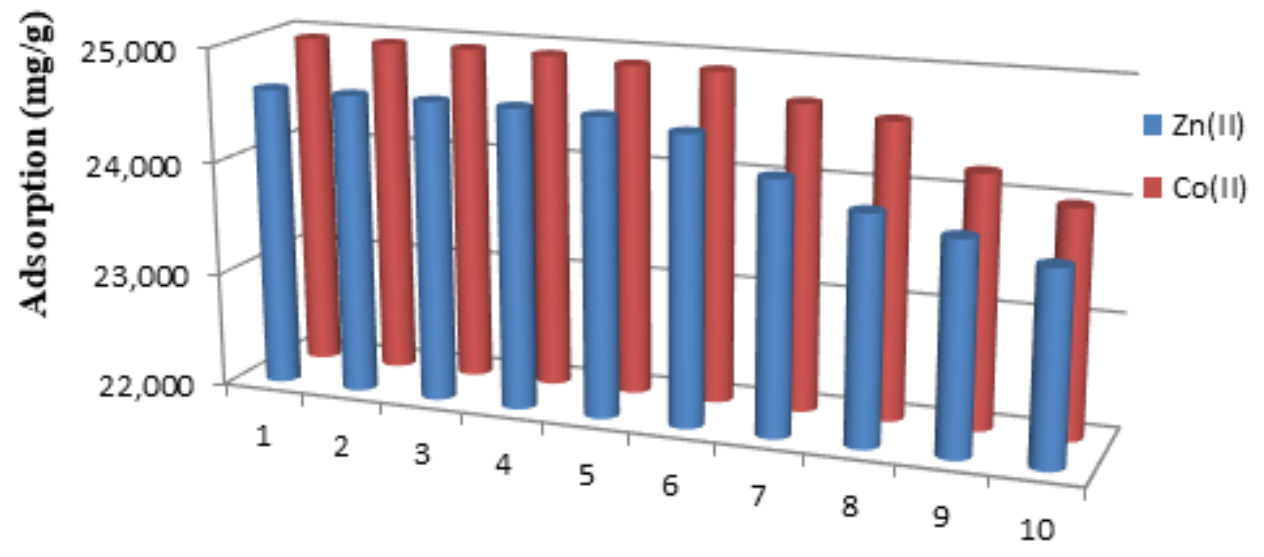

Figure 12

Reusability of the hybrid material for Co(II) and Zn(II) adsorption. 

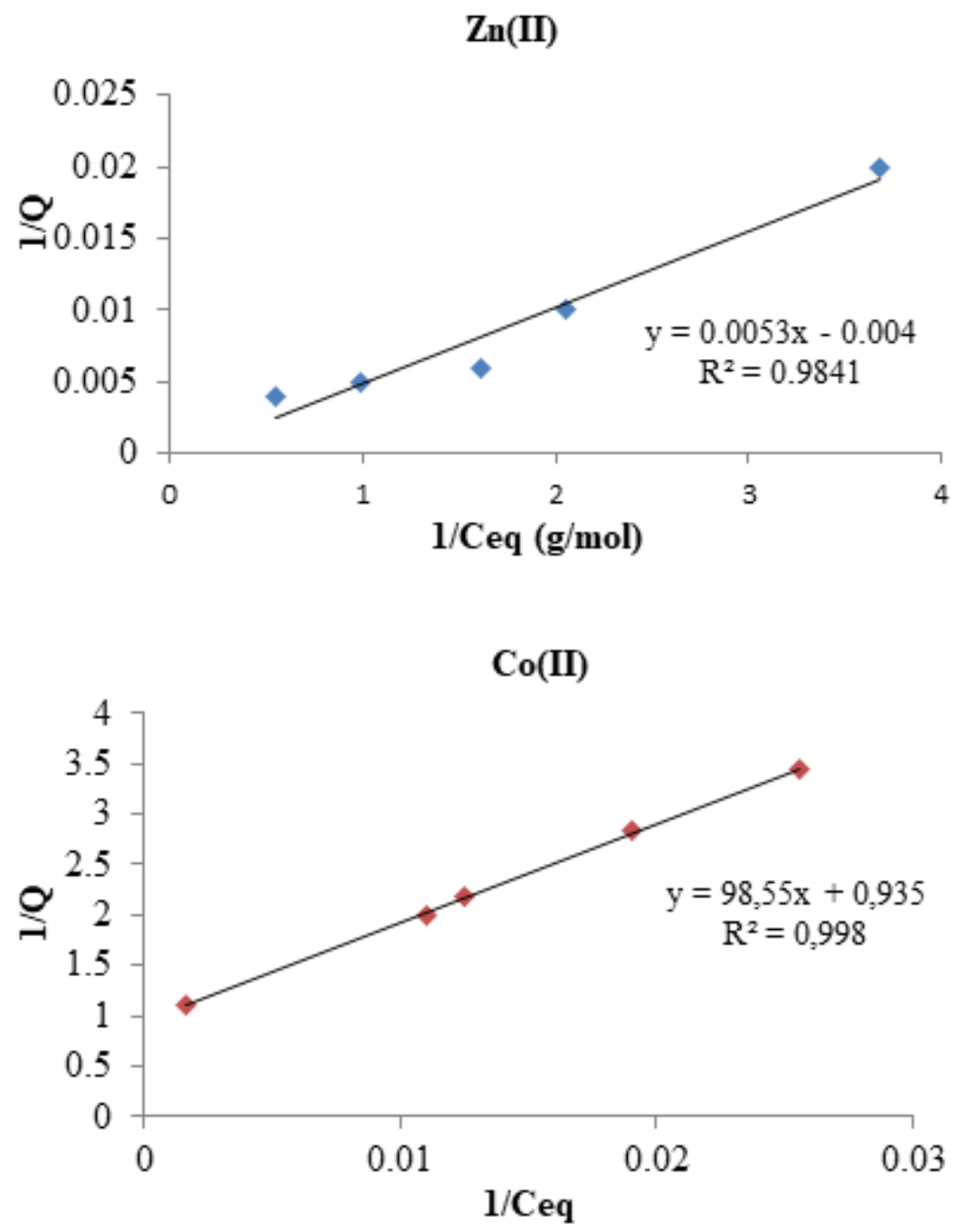

Figure 13

Langmuir isotherm graphics for $\mathrm{Zn}(\mathrm{II})$ and $\mathrm{Co}(\mathrm{II})$.

\section{Supplementary Files}

This is a list of supplementary files associated with this preprint. Click to download.

- GraphicalAbstract.docx 